\title{
Moderate Islam in Indonesia: Islamic Da'wah Activities of Ahmad Syafii Maarif
}

\author{
Suhaimi $^{* 1} \&$ Raudhonah $^{2}$ \\ ${ }^{12}$ Universitas Islam Negeri Syarif Hidayatullah Jakarta \\ * email.suhaimi@uinjkt.ac.id
}

\begin{abstract}
This study aims to observe Ahmad Syafii Maarif's preaching activities as a manifestation of Islamic moderation in the frame of humanity and Indonesian-ness. In his various ideas, Ahmad Syafii Maarif always presents an inclusive and tolerant portrait of Islam in Indonesia. His construction of Islamic da'wah is based on the doctrine of Islam as a religion of enlightenment that is rahmatan lil alamin. The research was conducted through a literature study by examining Abmad Syafii Maarif's ideas. Data collection was carried out through discourse analysis and interviews. The results of this study show that the figure of Buya Syafii Maarif carrying out moderate Islamic da'wah activities or persuasive Islamic preaching by interpreting makruf as something that is known and accepted by reason and society. Whereas munkar is something that is rejected by common sense. Syafii Maarif's moderate da'wah activities are conceptualized into three main Islamic ideas, namely Islam, humanity, and Indonesians. Ahmad Syafii Maarif consistently preaches persuasive and rational Islam, not intimidating preaching. Also, the existence of the Maarif Institute aims to facilitate activities to voice out his thoughts on Islamic teachings so that the character and uniqueness of moderate Indonesian Islam can be socialized.
\end{abstract}

Keywords : Moderate Islam; Da'wah of moderate Islam; Persuasive Islamic Da'wah;

\begin{abstract}
ABSTRAK
Penelitian ini bertujuan meneropong aktivitas dakwah Ahmad Syafii Maarif sebagai manifestasi moderasi Islam dalam bingkai kemanusiaan dan keindonesiaan. Ahmad Syafii Maarif dalam berbagai gagasannya selalu menampilkan potret Islam di Indonesia yang inklusif dan toleran. Konstrusi dakwah didasarkan pada doktrin Islam sebagai agama pencerahan yang rahmatan lil alamin. Penelitian dilakukan melalui pendekatan kepustakaan dengan mengkaji berbagai gagasan Ahmad Syafii Maarif. Teknik pengumpulan data dilakukan melalui pendekatan analisis wacana dan wawancara. Hasil penelitian menunjukkan sosok Buya Syafii Maarif menjalankan aktivitas dakwah Islam moderat atau dakwah Islam persuasif dengan memaknai makruf sebagai sesuatu yang dikenal dan diterima oleh akal maupun oleh masyarakat. sedangkan munkar adalah sesuatu yang ditolak oleh akal sehat. Aktivitas dakwah moderat Syafii Maarif dikonsepsikan ke dalam tiga gagasan keislaman utama, yakni keislaman, kemanusiaan dan keindonesiaan. Ahmad Syafii Maarif konsisten melakukan dakwah Islam persuasif dan rasional, bukan dakwah intimidatif. Selain itu, keberadaan Maarif Institute bertujuan untuk kelancaran kegiatan menyuarakan pemikirannya tentang ajaran Islam sehingga tersosialisasikannya watak dan ciri khas Islam Indonesia yang moderat.
\end{abstract}

Kata kunci : Islam moderat; Dakwah Islam moderat; Dakwah Islam persuasif; 


\section{INTRODUCTION}

Over the last decade, various violence in the name of religion, such as the suicide bombing in churces in Semarang (2011), M.H. Thamrin street, Jakarta (2016), a churce in Surabaya (2018) clearly show that the existence of extreme Islam is very dangerous. Extreme Islam not only kills people, but can also ignite horizontal conflicts between religious believers.-Extreme Islam can also endanger the unity and integrity of the Unitary State of the Republic of Indonesia (NKRI). In fact, it can also be a threat that will destroy the Republic of Indonesia. ISIS, Jameeat Islam, Ansar Daulah etc., all of them use Islamic label in their propaganda. But, ironically, their actions were contrary to Islamic values.

Extreme Islam, sometimes also called Radical Islam, is any form of Islam that opposes democracy, rule of law, individual freedom, and mutual respect and tolerance of various religions and beliefs. Extreme Islam in practice often infiltrates and politicizes religion for political purposes. They propagate for the establishment of a State of Religion or a State of Islamic Sharia - as a proxy or perhaps camouflage. In fact, Pancasila has been accepted as a Joint Consensus, as a Meeting Point of the values of various religions and ethnic groups in Indonesia, which in the term of the Qur'an is referred to as 'Kalimat Sawaa' or 'Common Denomination of Values'.

Extreme Islam grew and thrived after The Arab Spring which emerged in 2010. The Democratic Revolution which turned anarchist and tore apart the Arab nations also made the face of the Islamic world looked so dark. The violence and terror in the name of Islam have also tarnished the face of Islam which claims to be the religion of Peace and Grace.

Extreme Islam easily entered Indonesia in the Reformasi era, where the Indonesian government started to loosen its control over the flow of foreign power entering the country due to the turmoil of the democratic trend. The movement also supported by the development of communication technology (ICT), including the internet, which marks the era of globalization. With all these factors, extreme Islam, which became known as Transnational Islam, thrives in Indonesia. Its preaching reaches out to people from almost all groups and classes. In short, all groups in society are vulnerable to being exposed to extreme Islamic preaching. The Extreme Islam group sometimes camouflages itself as Salafis in an attempt to manipulate the word Salafiyah, which has been well known and familiar to Nabdhiyin. In this sense, the preaching of Extreme Islam is indeed a serious threat to the Republic of Indonesia: now and future. Therefore, it is necessary to rebuild the Moderate Islamic da'wah movement which is expected to be an antidote or a cure to the spread of extreme Islamic preaching.

Moderate Islam is Islam that is characterized by its support to a tolerant 
and inclusive religious attitude, promote the upholding of democracy, rule of law and individual freedom. Moderate Islamic da'wah in Indonesia can be traced from the history of the spread of Islam in Indonesia. It was clear that the first Islamic preaching in Indonesia was moderate Islamic preaching. It brought by Da'i, namely traders and scholars (ulama) who came from Arabia, India, and China who were generally Sufis. They are also called the Wali (the Saints) in the Sufism tradition. Islamic da'wah was carried out peacefully through trade as well as acculturation. Moderate Islamic preaching waas definitely the key to the success of Islamic preaching in Indonesia.

With regard to the current and future latent threat of extreme Islam for Indonesian Muslims, research on moderate Islamic da'wah is very important and imperative. The da'i must be prepared to have adequate knowledge and insight about moderate Islam. Islam is a blessing for everyone — including nonMuslims, even atheists, and to the universe. Its blessing delivers through persuasive da'wah and not force or coercion. The approaches have been applied by moderate figures such as Ahmad Syafii Maarif. He is a prominent Muslim intellectual, an activist; and with his intellectual horizon, he delivers Islamic voice to all people, not only Muslims but to people who have not converted to Islam, through his interfaith activities. To optimize his activities in delivering his thoughts on Islamic teachings, Syafii Maarif and his friends founded the "Maarif Institute for Culture and Humanity," which was officially established on February 28, 2003 in Jakarta.

The research entitled Moderate Islam in Indonesia: Ahmad Syafii Maarif's Islamic Da'wah activities is library research using a Historical Approach. As a socio-intellectual and religious history study in Indonesia, this research will apply three (3) types of studies, namely the study of text, context, and study of the relationship between texts and society about how Islamic da'wah activities are in our lovely Indonesia. Speaking of moderate Islamic preaching in Indonesia, it is hard to not mentioning Ahmad Syafii Maarif, often called Buya Syafii Maarif, as its avant-garde figure.

This study is distinct from other previous studies that discuss related issues. Muhammad Saleh (2004), for instance, in his thesis at UIN Jakarta, studied the Muhammadiyah movement and its position "in politics in the era of Amien Rais and Syafii Maarif's leadership". The study focused on the development of the Muhammadiyah movement and its work, as well as explaining how Muhammadiyah involved in politics in the era of Amien Rais and Syafii Maarif. Our study, however, focuses on moderate Islamic da'wah activities of Ahmad Syafii Maarif, especially explaining the thoughts of Syafii Maarif in disseminating Islamic teachings both to Muslims and to people who are not yet Muslim. His da'wah is carried out through his writings or through his speeches that consistently invite others to become better, fairer, and helpful 
Subaimi \& Raudhonab

people and always based on the Quran and Hadith. Because of his broad knowledge, creative and flexible thinking in conveying Islamic teachings to the public, the writers argue that Ahmad Syafii Maarif (hereinafter referred to as Syafii Maarif) is one of important the da'wah figures in Indonesia.

Abdul Rohim Ghazali and Saleh Partaonan Daulay (2005) edited a book entitled Muhammadiyah and the Politic of Inclusive Islam: 70 years of Ahmad Syafii Maarif which highlighted a glimpse of Syafii Maarif's da'wah thoughts. The writers in the book mostly described the figure of Syafii Maarif in the context of Muhammadiyah and Politics. Rizal Sukma wrote an article entitled "Muhammadiyah and Politics: Reflections for 70 years of Syafii Maarif"; Tarmizi Taher's article was entitled "Syafii Maarif, Muhammadiyah, and Politics"; Abd. Rohim Ghazali wrote an article entitled "Inclusive Islamic Politics: Considering Ahmad Syafii Maarif's Ideas"; Saleh Partaonan Daulay's article entitled "Muhammadiyah Politics: For Power or Nationality"; and Ahmad Fuad Fanani wrote an article with a title "Muhammadiyah's Dilemma and Finding a Solution". In fact, the discussion about Muhammadiyah and politics cannot be separated from his thoughts in the field of da'wah.

Some writers in the book took particular look at Syafii Maarif's preaching thoughts. M. Syafii Anwar wrote an article entitled "Syafii Maarif, Bung Hatta, and the Deformalization of Shari'ah". He discussed Syafii Maarif's thought which argued that when we approach the Qoran with a clean and clear heart and mind, and with reasonable knowledge and insights, we will find an inclusive and tolerant Islamic insight. Syafii Maarif, as noted by Ghazali (2005), argued that Islam is a very tolerant religion, even to atheism. In the design of the Quran, Islam serves to organize an inclusive and pluralistic socio-political life as practiced by the Prophet Muhammad through the Medina Charter. Likewise, Azra (2002) wrote about "Historical Limbo and Buya Syafii", in which he examined three Syafii Maarif's thoughts for getting out of the limbo of the history of the nation's problems. First, we must be able to embrace the Quran again. Second, leaving the mentality of being colonized. Third, don't abandon the Quran, hold it, and do not leave it (Ghazali \& Daulay, 2005).

A study from Putra (2013) focused on Syafii Maarif's thoughts by looking at his intellectual portraits on economic and political relations with historical, philosophical, and sociological approaches. He studied how Syafii Maarif's intelectual response to the economic and political conditions of Muslims in the dynamic's context of Indonesian democracy. Damanhuri (2015), meanwhile, examined Syafii Maarif's thoughts on Islam, Indonesia, and progress (kemajuan). Damanhuri categorized Syafii Maarif as a neo-modernist thinker whose intellectual construction was based on Qur'anic moral ethics. The implications of Maarif's thoughts were manifested in the spread of idea of peace and human values in Indonesia. Another study from Ali (2016) focused on the perspective of Ahmad Syafii Maarif on Islamic education. His research showed that Syafii 
Maarif's idea about education is characterized as critical-religious. Maarif's idea about education was built upon the dynamics of Islamic intellectual which is exposed to an inclusive Islamic culture. This is also a response to the condition of Islamic education which is dichotomic, backward, and lack of thought.

Muthoifin (2017) studied Syafii Maarif's perspective about the concept of the advancement of Islam (Islam berkemajuan) in the frame of humanity and 'Indonesian-ness' (Keindonesiaan). His research explored Syafii Maarif thought in promoting the discourse on the harmonious relation between Islam, humanity, and 'Indonesian-ness' as a foundation in creating the doctrine of Islam rahmatan lil alamin in the archipelago. Another study from Qorib (2017) analyze the construction of Syafii Maarif thougth from socio-cultural perspective. Qorib concluded that the Syafii maarif Islamic thought was influenced by his cultural background as meaning people who also have solid intellectual tradition in his family. His Islamic thought is characterized by using Al Quran as framework of thingking and history as an analytical tool. Study from Wulan Sari (2018) identified Syafii Maarif ideas about secularization of ulama and politic in Indonesia. Sari's study took a case study of the participation of Ma'ruf Amin (Head of MU) as one of vice president candidate in 2019 presidential election. Syafii Maarif argued that the involvement of religious figure in practical politic (politik praktis) or particular identity politic will threat the harmony of kebangsaan dalam bingkai diversity and unity. Therefore, the term of secularization of ulama and politic becomes an imperative to save the unity of Indonesia.

Research that focuses on the Muhammadiyah institution as a space for the actualization for Syafii Maarif in his moderate da'wah has been conducted by Darajat (2017). Darajat compared the moderate propagation of Islamic mass organizations between Muhammadiyah and NU. The results of his research showed that Islam in Indonesia can still be considered as moderate Islam. In this respect, both Muhammadiyah and NU are seen as custodians of Islamic moderation in Indonesia. Another relevant study from Fithriyyah and Umam's research (2018) looked at the strategic role of NU and Muhammadiyah mass organizations in the era of the Industrial Revolution 4.0. They showed that these two Islamic organizations consistently spread moderate da'wah values and utilize digital technologies in promoting counter-narrative of radicalism in digital spaces.

Taking a wider perspective, Asroor's research (2019) analyzed the dynamic transnational and moderate Islam in Indonesia. His study examined how Hizbut Tahrir Indonesia (HTI) infiltrated two Islamic organizations in Indonesia, NU and Muhammadiyah. The study showed that the idea of Islam Nusantara (NU) and the Advancement of Islam or Islam Berkemajuan (Muhammadiyah) became the foundation to prevent the idea of "Khilafah" in Indonesia. Yulianto's 
research (2020) on the moderation of Muhammdiyah in Indonesia, showed that moderate da'wah was carried out as counter-radicalism, extremism, and violence. There are at least three concepts of Muhammadiyah moderation, namely Tawassuth, Tasamuh, and Shura.

The studies above show that the moderation of da'wah in Indonesia is an important concept for spreading the values of peace, humanity, and nationality. As one of Indonesia's Muslim intellectuals, Ahmad Syafii Maarif has consistently voiced out moderate Islam in the world stage. This is shown in his various responses to the condition of Islamic life, humanitarian, and Indonesia. This study, therefore, aims to analyze the construction of moderate da'wah from the perspective of Syafii Maarif which is studied through a series of his da'wah activities in various places and conditions. This approach makes this study different from previous studies, as the study is focused on Ahmad Syafii Maarif's preaching activities in spreading Islam rahmatan lil alamin.

\section{RESULT AND DISCUSSION}

\section{Ahmad Syafii Maarif on Moderate Islamic Da'wah}

Da'wah has become a daily word for Indonesian Muslims, therefore the meaning of the word "da'wah" is considered finished. It's been taken for granted. In fact, "da'wah" is a specific term known in the Islamic world as the mandate of the Prophet Muhammad SAW. Islamic da'wah started since the Prophet Muhammad SAW was appointed a Prophet. He started Islamic da'wah activities by delivering prophetic messages. As in the Protestant world, there is also the term "zending". In Hinduism Dharma is known as the term "Dharma". Both of which have almost the same meaning as "Islamic Da'wah".

The word 'da'wah' is etymologically (language) taken from Arabic دعوة, which is the root word (masdar) from the verb da'a- yad'u, da'watan which means "call, exclamation (seruan), or invitation" (Munawwir, 1984: 439). In the ودعوى ه gardionary al-Munjîd (Ma'luf, tt: 216), the word 'da'wah' takes the word ناداه دعich means "call", رعا يدعو دعا "tend/invite", and إستب "request". In the oral dictionary al-A'rab, the word 'da'a' --- a verb derived from Da'wah-has two meanings, namely: إستغاثة (request, prayer) and عبادة (devotion) to Allah SWT. (Al-Ansari, tt: 281)

Yusuf Qardhawi (1992: 12) in the book al-Shahwah al-Islamiyyat wa Humum al-Wathan al-Arabiy wa al-Islamiy, states that da'wah is an invitation to uphold Islam among Muslims themselves so that there is a compatibility between the realities of a Muslim's life with his aqidah, as well as the compatibility between his behavior and his conscience.

Meanwhile, Maarif (1995) who is persistent in advocating moderate Islamic da'wah and the founder of the Maarif Institute Foundation explained: "Da'wah must be carried out as long as human activities are still allowed to take 
place, it is also the obligation of Muslims to convey the prophetic message in any condition and situation. The contents of the message are essentially the eternal demands of the human conscience throughout the ages" (Maarif, 1995: 102).

Moderate Islam is a religious model of Islam that refers to the original teachings of Islam based on Al-Qur'an and the Sunnah. Moderate Islam attempts to present the true Islam which is a religion that teach preach as Salaam, peace of life (Maarif, 1995: 101). Islam is a blessing for everyone including non-Muslims and even atheists - as well as to the universe. It is delivered through persuasive preaching while staying away from preaching that uses violence or coercion. Moderate Islamic preaching is also the work and activities of goodness through the preaching of bil al-Lisan, preaching, bil al-Hal - including preaching with the example of the life of the preacher (da'i) himself and also the preaching of bil Qalam, as exemplified by Buya Syafii Maarif.

Islam is a religion of Peace (assalaam, a Peace). In a famous Hadith narrated by Imam Bukhari and Muslim, Rasulullah SAW firmly reminded: "A Muslim is a person who is safe from other people's verbal and hand disturbances." The holy book of the Qur'an itself affirms that Islam was revealed as "the grace of the entire Universe". Islam is a religion of "rahmatan lil alamin" As stated in the Qur'an, Surah Al Anbiya verse 107 which means: "And we did not send you (Muhammad), but to (be) a mercy (rahmat) for the universe." As a grace, Islam must be a religion that can bring a sense of peace and serenity. Islam is not a threat to be afraid of. Moreover, Islam is not a source of terror and crimes against humanity. Terror and crimes contradict the very purpose and essence of Islam.

The meaning of the sentence "rahmatan lil 'alamin", according to M. Quraish Shihab (2000: 52-56), implies that the figure of the Prophet Muhammad SAW with the teachings he carries (Islam), is a blessing for the universe. Grace is meant to include humans, plants, animals, as well as inanimate objects. For Buya Syafii, Islam is understood as a religion that explicitly offers the principle of balance to humans, because the goal to be achieved by Islam is the upholding of the principles of equality, justice, brotherhood, and tolerance. This view is based on several verses in the Qur'an; al-Hujurât, 49:10, 13 and 15; an-Nisâ ', 4:58; anNahl, 16:90; al-Maidah, 5: 8; al-Zumar, 39:18; al-Baqarah, 2: 256 (Damanhuri, 2015: 81).

The attitudes that are beyond the limit or extreme are excessive religious attitudes. Radical or Extreme religious attitudes. Extreme in the language of religion is called "at-tatarruf" attitude. The extreme attitude that beyond limits. It can be extreme left or right. Leftist, which is often understood as being too strict, creating an attitude of "at-tasaddud" or "sadid" or "sadistic" in religion. Syafii Maarif places Al-Quran as a moral source for humanity and justice. For him, Al-Quran is a critical reflection in answering the problems of humanity 
Subaimi \& Raudhonah

which are always being seen from a dichotomic Islamic point of view. An extreme attitude that places diversity as a difference that potentially causing humanitarian conflict (Qorib, 2017: 71).

In Surat Al-Baqarah verse 143 it is reminded that Muslims should be fair. They have to stand in the middle when practicing their religion. Muslims must stand between the hard and the soft. Muslims must be tawasauth or moderate as stated in the words of Allah SWT which means: "And thus We have made you, ummatan wasathan so that you become syuhada for humans and for the Prophet (Muhammad) to become syahid for you."

According to Shihab (2000), a moderate attitude is actually an ideal illustration of a society. In the end, a moderate society will be able to create harmony and continuity. This is the other side of the concept of ummatan wasathan.

Moderate Islamic Da'wah is Islamic da'wah which fights for Islamic teachings to return to original and authentic teachings sourced from the Qur'an and Sunnah. Both of which are the main sources for the establishment of the pillars of an ideal life order for Muslims in order to create Islamic brotherhood as well as human brotherhood. Moderate Islam strives so that the noble Islamic teachings are not contaminated by short-term interests, including political interests that can damage the teachings of Islam. Syafii Maarif believes that the relations of Islam, humanity, and 'Indonesianness' are inseparable relations. This relationship goes hand in hand with changes in society in a socio-cultural context. Islam as a historical religion will continue to struggle with changing situations. The goal of Islam is to direct these changes to remain within the corridor of Islam, namely civilization, humanity, and justice. In his view, Islam is not hard, violent, terror, and radical (Muthoifin, 2017: 124).

Moderate Islam has to be the mainstream in Indonesia in its effort to uphold the Islamic order with its Pancasila. The moderate Islam has been exemplified by Rasullah SAW with the people of Medina through the Medina Charter which ensured that everyone has the right to be protected and live peacefully in the Muslim majority community of Medina.

\section{Ahmad Syafii Maarif Mainstreaming Moderate Islam with Muhammadiyah}

As a Muhammadiyah figure, Buya Syafii Maarif once held the position of Chairman of the Central Executive of Muhammadiyah (2000 - 2005), replaced Amien Rais. Muhammadiyah is a very large and influential Indonesian Islamic organization. Muhammadiyah was founded in Kauman Village, Yogyakarta, on 8 Dzulhijjah 1330 H / 18 November 1912 by a Muhammad Darwis - a name which was later famously known as K.H.Ahmad Dahlan.

He was a Khatib of the Yogyakarta Sultanate. The driving factor of the establishment of Muhammadiyah was the poor condition of the ummah's 
education. Furthermore, the religious practices were stagnant and full of mystical practices--occult and Javanese cult (Kejawen). KH Ahmad Dahlan was moved to invite the ummah back to the true teachings of Islam based on the Qur'an and Hadith. The pure Islam.

The name 'Muhammadiyah' itself was a name that created many interpretations. According to Suwarno (2001), the name "Muhammadiyah" is associated with the notion that the Muhammadiyah organization is a follower of the Prophet Muhammad, who tried to preach Islam by following his way. Some people also say that the name is associated with the name Muhammadiyah School which he founded in 1911. However, there are also those who say that the name was actually the name proposed by the senior of K.H. Ahmad Dahlan, namely Muhammad Sangidu who was also the Khatib in the Yogyakarta Sultanate.

Looking at people around him who were already Muslim but unable to get away from the practice of Tahayyul, Bidah, and Churofat, K.H. Ahmad Dahlan hold religious teaching (pengajian) at his house. Islamic Da'wah of K.H. Ahmad Dahlan was not immediately accepted by the people around him, yet he continued to carry out his Da'wah duties with extraordinary sincerity and determination. K.H. Ahmad Dahlan was a Da'i who followed the way of the Prophet Muhammad who was patient and persistent; invite in ways to provide exemplary, noble morals.

Da'wah Islam of Muhammadiyah is a moderate Islamic da'wah that uses cultural strategies through charities which cover the fields of Education, Social, Economic, and Community social life. Muhammadiyah school was the pioneer of the Muhammadiyah da'wah. Through its business and charity, Muhammadiyah was later able to be a successful Islamic organization in managing modern educational institutions. Currently, Muhammadiyah already has 166 universities, as stated by Haedar Nashir.

The cultural da'wah strategy has been cleverly chosen to achieve Muhammadiyah's vision "to create a just and prosperous country that is blessed by Allah. "Baldatun tayyibatun warabbun ghafuur". This moderation of Islamic da'wah was developed based on the view that Islam is a religion of enlightenment. In the context of the ummah life, the enlightening religion offers a way of transformation (strategy of progressive change) towards the realization of the best people or khairu ummah (Surah Ali Imran: 110). Khairu ummah has the character of an ummathan wasathan and syuhada 'ala al-nas (Surah AlBaqarah: 143). This is the idealization of the society that is coveted in the construction of enlightening Islamic theology (Yulianto, 2020: 75).

Islam is truly a religion that carries the mission of advancing human civilization. It is known as din al-hadharah or religion of advancement. The advancement of Islam radiates enlightenment for life. The advancement of Islam 
Subaimi \& Raudbonah

creates advancement that theologically is a reflection of the values of transcendence, liberation, emancipation, and humanization contained in the message of Al-Qur'an Surah Ali Imran verses 104 and 110 which become the inspiration of Muhammadiyah (Yulianto, 2020: 81).

Muhammadiyyah as a moderate organization characterized by an inclusive way of thinking, dynamic, and respects the cultural aspects of society. At the 47th Muhammadiyah's Congress which took place in Makassar, South Sulawesi (2015), Muhammadiyah raised the theme "Enlightenment Da'wah Towards the advancement of Indonesia". One of the important things discussed in the congress was about the organization's commitment to safeguarding the state's foundation of the Pancasila and Indonesia as Darul 'Ahdi Wassyahadah, the country of agreement and consensus. At this point, Muhammadiyyah has mainstreamed Islamic moderation in fighting radical, terror, and extreme religious ideas (Asroor, 2019: 206-208). This moderate da'wah is carried out as an effort to counter the narrative of radicalism and against transnational Islam which has recently grown and developed in Indonesia. In addition, the Muhammadiyah enlightenment movement was conceived as an effort to bring about transformative change based on the needs of the ummah and the challenges of Islam globally.

\section{Moderate Islamic Da'wah of Ahmad Syafii Maarif}

His full name is Ahmad Syafii Maarif. He is often referred to as "Buya" as an ulama from Minang, West Sumatra by people close to him. However, Syafii Maarif himself said, "don't need to be called Buya." Sometimes Syafii Maarif "likes to mislead the word as "Buaya" (Crocodile)", as if he tries to neutralize or avoid the " charismatic" or "feudalistic" value of the word Buya (Ghazali \& Daulay, 2005: 37).

Syafii Maarif is a doctor who graduated from the West, so he is sometimes accused of being a Western agent or supporter of the Secularists. He is an alumnus of the University of Athens, Ohio for his Masters and the University of Chicago for his Doctorate. He is known to be very keen on reflecting the objective reality of Muslims in history with the sacred Islamic doctrines in the Qur'an and Hadith. This was done not only for Muslims but also for people across faiths and religious beliefs, even across countries. Because of his struggles, he was awarded the Magsaysay Award by the Ramon Magsaysay Foundation in 2008.

Syafii Maarif was born in Sumpur Kudus, West Sumatra on May 31, 1935, to Ma'rifah Rauf (1900 - 1955) and Fathiyah (born ca.1905 - 1937) (Maarif, 2006: viii). He started his education at SR (People's School of Sekolah Rakyat) or Elementary School (SD). He then went to Muallimin in Lintau village which was relatively more developed than his village, Sumpur Kudus, and then continued to Muallimin Muhammadiyah School in Lintau. Syafii Maarif believes that the 
Goddess of Fortune (Fortuna) will not come from heaven to help and change someone's fate. In addition to being in the hands of Allah SWT, his fate will depend on his own effort. God only willing to intervene when humans take the initiative to determine their own future (Maarif, 2006: 52).

Syafii Maarif was elected as a Chairman of the Muhammadiyah Central Executive (1998 - 2005), which has brought Syafii Maarif to the national stage of political, social, and cultural development (Maarif, 2006: 405). Yet, he is known as the chairman of PP Muhammadiyah who continued to make Muhammadiyah firm on the Khittah, not tempted by politics and power.

Syafii Maarif is one of the few productive intellectual figures of Indonesian Muslims. He delivers his da'wah by writing down his ideas and thoughts to inspire and awaken the people, to voice out various issues of Islam, Indonesia, and humanity. Among his works are: Titik Kisar in Perjalananku: Otobiografi Ahmad Syafii Maarif (2006), Islam dan Pancasila sebagai Dasar Negara Studi tentang Perdebatan dalam Konstituante, edisi revisi (2006), Menerobos Kemelut Refleksi Cendikiawan Muslim (2005), Mencari Autentisitas Dalam Kegalauan (2004), Menggugah Nurani Bangsa (2005), Independensi Muhammadiyah di Tengah Pergumulan Pemikiran Islam dan Politik (2000), Islam dan Politik Membingkai Peradaban (1999), Islam Kekuatan Doktrin dan Keagamaan Umat (1997), Ibn Khaldun Dalam Pandangan Penulis Barat dan Timur (1996), Islam dan Politik Teori Belah Bambu Masa Demokrasi Terpimpin (1959-1965) pada tahun (1996), Membumikan Islam (1995), Peta Bumi Intelektual Islam Indonesia (1993), Islam dan Politik di Indonesia (1988), Al-Qur'an, Realitas Sosial dan Limbo Sejarah (Sebuah Refleksi) (1985), Islam dan Masalah Kenegaraan (1985), Percik-percik Pemikiran Iqbal (1984), Islam, Mengapa tidak ? (1984), Dinamika Islam (1984), Mengapa Vietnam Jatuh Seluruhnya ketangan Komunis (1975).

$\mathrm{He}$ is a da'i who is persistent and consistent with his ideas and thoughts. For him, da'i's words must be in accordance with his deeds. As a dai, he is actively involved in upholding legal justice, fighting corruption, discrimination, conducting inter-religious dialogue, and also protecting several institutions such as Muhammadiyah, the Maarif Institute, Muhammadiyah Schools - Muallimin Yogyakarta, his former address. Islamic Da'wah, according to Syafii Maarif, is a work of 'salting' (menggarami) the life in which Da'wah needs to be appropriate and flexible as well as creative in order to be effective and reach the target.

The Islamic da'wah which intensively carried out by Syafiri Maarif included three things. These three things became the platform for Syafii Maarif's struggle, namely Islam, Indonesianness, and Humanity. The three of them form an organic and inseparable unity, namely Islam, Indonesia, and Humanity. These three things are a manifestation of Syafii Maarif upon various contemplations and critical reflections on the condition of the ummah. Buya Syafii stated four things that made him worried. First, he does not want this nation to be torn 
apart by religious politics, petty interests, local interests, and primordialism. Second, there is a gap between the teachings and the practice of life, there is an absence correlation between religious practice and moral improvement. On one hand, people are diligent in worship. However, on the other hand, corruption is increasingly prevalent and violence destroys this nation. Third, the emergence of diseases that are cultural and mental in nature. And fourth, the phenomenon of poverty and ignorance afflicts the majority of Indonesian Muslims (Damanhuri, 2015: 82).

Speaking about Islam, according to Syafii Maarif, "If the process of internalizing religious values has occurred in us as a nation, religion will certainly function as guidance of behavior, both in individual and collective life. That way, their activities can be correct and have a clear purpose; they can do the right things and avoid the bad ones, in accordance to the rules in religion. In turn, it will create peace and there will be no abuse of authority" (Maarif, 1995: 109).

Regarding Indonesianness (Keindonesiaan), Syafii Maarif stated that the Republic of Indonesia is not a religious state. But, also not a secular state. The Republic of Indonesia is actually a country that is built based on the essence of universal Islamic values, as reflected in the Pancasila. Therefore, anyone must protect the Republic of Indonesia (Maarif, 2006: 13). Therefore, when the issue of Islamic law arose in Indonesia, it was clear that Syafii Maarif was not antiIslam, let alone Islamophobia. Syafii Maarif views that the Republic of Indonesia with its philosophy of Pancasila is a gift that must be guarded by Muslims. Pancasila is also considered to be final as the best (foundation) because it is the result of a consensus similar to the famous 'Medina Charter'.

For Syafii Maarif, the emergence of the idea of an Islamic State was mostly caused by the reactive attitude of the ummah towards the development of the 20th-century political century, not by sincerity to create an Islamic life order that is comprehensive, intact, and substantial. They are more interested in the shape or presentation than in the substance. And herein lies the tragedy of vigorous movements to create an Islamic State. (Maarif, 2004: 69-70).

Meanwhile, talking about Humanity is talking about Economy and Justice, about Education and Culture. The three of them are related. In a good cultural building, there will be a just economic system that does not exploit other people. According to Syafii Maarif, the background of Islamic Da'wah is in fact an unfair economic situation. It was economic injustice that prompted Muhammad to be alone in Hira Cave repeatedly, in order to find a solution to this social inequality. And, in this cave, according to history, the first revelations came to the prophet (surah al-'Alaq 1-5) (Syafii Maarif, Resonansi in www.maarifinstitute.org. Date 15-5-2007).

According to Syafii Maarif (interview, November 2008), even though it has been almost 1 century of Indonesia being independent, Economic and Social Justice has not materialized, even the poverty rate has skyrocketed. Inequality is 
increasing, corruption is rampant. The rich are getting richer and the poor are getting poorer. Economic and social justice is far from being a reality.

Syafii Maarif is a true da'i — although perhaps not quite popular among the grassroots. His whole life is almost fully dedicated to the preaching of Islam. Since graduating from Yogjakarta Muallimin School, he has immediately been involved in the world of da'wah. His deep understanding of Al-Qur'an and Sunnah which is supported by his broad and deep knowledge as well as his long experience as an activist and board member of PP Muhammadiyah have made him a da'wah model (da'i) that almost no one can achieve. Furthermore, his way of life is in itself forms Islamic da'wah which almost no preachers have: Syafii preaching Islam with exemplary. " Because of that, it is clear that Syafii Maarif is a truly authoritative da'wah model (reference) - who has the authority - to speak da'wah.

For Syafii Maarif, da'wah is an activity to call and invite anyone, including non-Muslims and even atheists - to make a change from bad conditions to good, even better ones, and to invite people to practice Islamic teaching and made it as a culture in his life (Maarif, 1985: 102).

Because Islamic da'wah activities are aimed at translating change or transformation, especially cultural transformation — therefore, da'wah activities must be carried out professionally in the sense that da'wah "requires special intelligence to carry it out". And, this must be supported by adequate education and expertise. To be able to become a professional, a da'i must spend a lot of money, that is why it is normal that da'i must be paid because da'wah is also his profession (Maarif, 2000: 43).

Many scholars refer to the letter Hud (11) verse 51, which means: "O my people, I do not ask you for wages for this call of mine. My reward is none other than Allah who created me...”. And also in Saba (34) verse 47, which means: "Say whatever reward I ask you, it is for you. My reward is only from Allah, and He knows all things." However, according to Syafii Maarif (interview, November 2008), if after carrying out his preaching or lecturing and then he is given payment, it must be believed to be his earning. Because the activity of preaching is worship which has a relationship to carry out the orders of Allah SWT and the prophet, the professionalism here is to work as best as he can and to be sincerely and tawakal for hoping to be pleased by Allah SW'T. A da'i must be able to be an example in words and action. He should do what he says. Do not violate it as it will damage the image of Islam.

Syafii Maarif (interview, November 2008) defined da'wah activities as follows: "Etymologically, da'wah is an invitation and call. Inviting and calling people to the way of Allah. Calling out the truth and others". So da'wah is all activities carried out to invite others to work on the truth that is pleased by Allah SWT: changing from bad to good and better. 
In "Al-Qur'an, Social Reality, and Historical Limbo", Syafii Maarif (1985) explained that da'wah is "an invitation to Islam by adopting flexible, creative, and wise methods. That way, da'wah is carried out in a wise way, directed to positive thinking, and not with violence, so that it fulfills the Da'wah with one's own awareness. From this point of view, tabligh is only one of the methods of da'wah Islam, because da'wah can be carried out in writing as well as actions. To be able to do so, the requirements to be a da'i are more difficult than those that are demanded to a muballigh as is known in our society" (Maarif, 1985: 102).

The religious awareness of Indonesian Muslims began to shift from the ideological thinking stage towards scientific thinking, or the period of ideas. In the period of ideas, Islam is understood in a scientific framework, religious teachings are formulated or interpreted into a set of theories which later become a framework for action, as a basis for action. In this case, Syafii Maarif classifies his Islamic foundation into two things, first, quranic Islam and historical Islam. In practice, these two Islamic ideas take the form of transformative action or change. It is transformative that becomes the goal in the actualization of Syafii Maarif's da'wah activities (Ali, 2016: 3-5).

The method of da'wah, according to Syafii Maarif, should follow what is taught in the Al-Quran - such as in Surah An-Nahl verse 125 - and the examples from Prophet Muhammad which include da'wah bi al-Hikmah (Wisdom), Mau'idah Hasanah (good advice) and Mujadalah bilati Hiya Ahsan (arguing in a good way) (Maarif, 1985: 102).

Syafii Maarif (interview, March 2008) emphasized the importance of Da'wah bil hal, as has been done by Rasulullah SAW. Because of that Da'wah that is, with his exemplary and noble character before becoming a Prophet, he earned the nickname al-Amin (trustworthy). This da'wah method could attract, the person of the Prophet is already a magnet or attraction in itself, as matsalul a'la (the highest example), it is not easy to do so. As a Prophet, he was always monitored by Allah SWT. As normal human beings, people are monitored by our conscience. In this case, Syafii Maarif's criticism of current preaching activities is that there are many da'i who are lack of qualifications due to inadequate education, only relying on rhetorical skills, without being accompanied by sufficient Islamic insights about the Qur'an, sunnah and history in following the teaching Rasulullah Muhammad SAW.

\section{Ahmad Syafii Maarif as an Icon of Moderate Islamic Da'wah of Maarif Institute}

Maarif Institute for Culture and Humanity is a means to accommodate and disseminate the big ideas and thoughts of Syafii Maarif as an activist, thinker, and da'i. Ahmad Syafii Maarif is one of those who took the initiative to establish the Maarif Institute for Culture and Humanity. While the others are Moeslim 
Abdurrahman, M. Amin Abdullah, Haedar Nashir, Rizal Sukma, Suyoto and Jefrie Geovannie (Ghazali \& Daulay, 2005: v)

Maarif Institute for Culture and Humanity was founded in Jakarta in 2002 and was officially established on February 28, 2003. Its birth started from the awareness of the importance of cultural institutions that fight for the socialization of the character and uniqueness of Indonesian Islam as a religion of rahmatan lil 'alamin, inclusive, and tolerant and compatible with democracy in favor of justice. In addition, the establishment of the Maarif Institute also originated from the main idea that in resolving the economic, political, and social damage crisis, it is necessary to have a "national tent" as an effort to consolidate all the forces of society that are outside of the state power and political parties. This is important, considering that the reformation (reformasi) agenda has not been effective until now (Ghazali \& Daulay, 2005: v).

After all, Syafii Maarif is a role model (uswah), the figure of a pluralist cultural Islam and a true reflection of the attitude of rahmatan lil 'alamin as the most basic Islamic teaching that being Islam is a humanitarian attitude that is good for anyone and anyone (Resonansi, http //www.maarifinstitute.org, 27/08/2007). The name of this institution - Maarif Institute - is not because it belongs to Syafii Marif or his wishes, but because the Maarif Institute also operates under the Ahmad Syafii Maarif Foundation (Interview with Raja Juli Antoni, 28/01/2008).

The vision of Maarif Institute is "The realization of Ahmad Syafii Maarif's social ideals and intellectualism to fight for the upholding of Islamic principles that are inclusive, tolerant, pluralist, humanist, civilized and peaceful as the foundation of democracy and social justice." In its struggle, the Maarif Institute aims to strengthen the roles and functions of civil society, legislature, and executive and to promote processes of conflict resolution, mediation, and reconciliation (Raja Juli Antoni, 2006-2007 Annual Report: 2).

Maarif Institute's da'wah activities are to invite and call for change to Muslims and non-Muslims, as children of the nation. Change towards improvement and welfare of life. Da'wah is carried out to awaken and mobilize community or nation to change for the better. The Da'wah of Maarif Institute is designed into programs that can be measured in terms of achievement, such as conducting research, publishing books and journals, holding national and international seminars/ symposiums, workshops, training, holding interfaith dialogues and giving the "Maarif Award" (Raja Juli Antoni, 2007).

\section{CONCLUSION}

Islamic da'wah includes all work and activities undertaken to call on and invite people to do good (al-maruf) and stay away from badness or evil (al-munkar). Work and da'wah activities that try to persuade Muslims to do the right things 
Subaimi \& Raudbonah

according to Islamic teachings, in order to get happiness in the world and in the Hereafter are activities ordered by Allah SWT. Doing da'wah activities is the noblest activity. And, because da'wah work and activities are to carry out the teachings of Islam, the work and activities of da'wah must be guided by the main sources of Islamic teachings, namely the Al-Qur'an and Hadith as well as History - especially the History of the Prophet Muhammad in preaching Islam.

Moderate Islamic da'wah is da'wah that calls on amar ma'ruf and nahi munkar by promoting tolerant attitudes (tasamuh), not using violent methods (non-coercion; non-violance; al ikraah), making it easy in practicing religion (samhah), inclusively embracing those with different views, respects those of different sects and schools of thought, puts forward the hablum minannas, strives to uphold a democratic and just order, builds harmony with those who are Muslims or non-Muslims as well, even with atheists. 'Islam is rahmatan lil alamin'.

Muhammadiyah is a very large Islamic mass organization that was once led by Ahmad Syafii Maarif. Since its establishment, it has chosen moderate Islam as its platform for its struggle to da'wah. It is a means of Islamic da'wah to participate in realizing the Republic of Indonesia that is just and prosperous and is blessed by God Almighty: baldatun thayyibatun warabbun ghafuur. In carrying out its Islamic da'wah, Muhammadiyah as a moderate Islamic organization chooses cultural preaching through Da'wah bil-Lisan, Da'wah bil-Hal and Da'wah bil-Qalam. Muhammadiyah maintains a harmonious distance from being involved in practical politics, as Syafii Maarif had fought for when he was chairman of PP Muhammadiyah.

Maarif Institute is a Humanitarian and Cultural institution that is also engaged in Moderate Islamic Da'wah by choosing a cultural approach as its Da'wah strategy. This institution was built to accommodate and disseminate the ideas and thoughts of Syafii Maarif as a Muslim intellectual and preacher who was concerned about preaching moderate Islam for the Republic of Indonesia. Maarif Institute also positions itself as a 'big tent' for anyone — including people and interfaith leaders — who have a spirit to build a better Indonesia by preaching universal Islamic values such as egalitarianism, justice, brotherhood, and humanism.

Ahmad Syafii Maarif's moderate Islamic da'wah is mostly delivered through his writings, where his main thoughts can be categorized into three major themes. The three themes are Islam, Indonesian, and Humanity.

Syafii Maarif's criticized that the current da'wah of Islam may lead to disaster if it is not immediately addressed. The infiltration of extreme Islam should be properly solved. The emergence of radical and extreme religious groups, both extreme right and left, could threaten Bhineka Tunggal Ika. It is possible Indonesia can be Afghanistan, Iraq, Libya, Yemen, or Syria, where Islam is not grace but a terrible weapon of mass destruction (lethal weapon). 
Therefore, moderate Islamic preaching needs to be mainstreamed in order to save and strengthen the people and the nation of Indonesia.

The professionalism of Islamic da'wah demands that preachers be able to carry out their da'wah duties effectively and efficiently, achieving their da'wah goals. A good Da'i is those who also willing and continue to learn to continuously open themselves and socialize with many people in order to understand the target of da'wah. Da'wah must be formulated with a good, attractive, flexible, and creative strategy.

\section{REFERENCES}

Al-Ansari, I.M. Lisan al- A'rab, Jilid 18, Kairo, Dar Al-Mishriyah Li al-Taklif, tt. 218.

Ali, M. (2016). Pemikiran Pendidikan Islam Ahmad Syafii Maarif, Profetika: Jurnal Studi Islam, 17(2), 1-14.

Asroor, Z. (2019). Islam Transnasional VS Islam Moderat: Upaya NU dan MD dalam Menyuarakan Islam Moderat di Panggung Dunia, At-Turäs: Jurnal Studi Keislaman, 6(2), 171-203.

Azra, A. (2002), Historiografi Islam Kontemporer, Wacana, Aktualitas dan Aktor Sejarah, Jakarta, PT. Gramedia, 2002.

Damanhuri. (2015). Islam, Keindonesiaan, dan Kemanusiaan (Telaah Pemikiran Ahmad Syafii Maarif), Jurnal Al-Banjari, 14(1), 76-84.

Darajat, Z. (2017). Muhammadiyah dan NU: Penjaga Moderatisme Islam di Indonesia, Hayula: Indonesian Journal of Multidisciplinary Islamic Studies, 1(1).

Fithriyyah, M.U., \& Umam, M.S. (2018). Quo Vadis Ormas Islam Moderat Indonesia? Meneropong Peran NU-Muhammadiyah di Era Revolusi Industri 4.0, Jurnal Politea, 1(1), 15-28.

Ghazali, A.B., \& Daulay, S.P (ed.). (2005). Refleksi 70 Tabun Abmad Syafii Maarif Cermin Untuk Semua. Jakarta: Maarif Institute.

Ghazali, A.B., \& Daulay, S.P (ed.). (2005). Muhammadiyah dan Politik Islam inklusif, Jakarta: Maarif Institute.

Maarif, A. S. (1985). Al-Qur'an Realitas Sosial dan Limbo Sejarah (sebuah Refleksi), Bandung: Pustaka.

Maarif, A. S. (1995). Membumikan Islam, Yogyakarta, Pustaka Pelajar.

Maarif, A. S. (1995). Peta Bumi Intelektualisme Islam di Indonesia, Jakarta, Mizan.

Maarif, A. S. (2000). Independensi Mubammadiyab; di Tengah Pergumulan Pemikiran Islam dan Politik, Jakarta, Cidesindo.

Maarif, A. S. (2004). Mencari Autentisitas Dalam Kegalauan, Jakarta, PSAP Muhammadiyah.

Maarif, A. S. (2006). Sinyal di Sumpur Kudus, dalam Resonansi, Republika, Agustus 2006.

Maarif, A. S. (2006). Titik-Titik Kisar di Perjalananku: Otobiografi Ahmad Syafii 
Maarif, Jogjakarta, Ombak.

Ma'luf, L. Al-Munjid al-Lughah Wa al-A'lam, Bairut, Dar al-Masyriq, 936.

Munawwir, A.W. (1984). Al-Munawmir Kamus Arab Indonesia, Yogyakarta, Pondok Pesantren Al-Munawwir Krapyak.

Muthoifin. (2017). Islam Berkemajuan Perspektif Ahmad Syafii Maarif (Studi Pemikiran Ahmad Syafii Maarif dalam Bingkai Keindonesiaan dan Kemanusiaan), Wahana Akademika, 4(1), 117-132.

Putra, A. (2013). Potret Intelektual Muslim: Sebuah Tinjauan Sosiologi Pengetahuan terhadap Pemikiran Ahmad Syafii Maarif, Jurnal Sosiologi Masyarakat, 18(1), 47-73.

Qardhawi, Y. (1992). Al-Shalwat al-Islamiyyat Wa Humum al-Wathan al-Arabi Wa al-Islami, Bairut, Mu'assasat al-Risalat.

Qorib, M. (2017). Ahmad Syafii Maarif: Kajian Sosial-Intelektual dan Model Gagasan Keislamannya, Jurnal Agama dan Pendidikan Islam Intiqad, 9(2), 6382.

Shihab, M. Q. (2000). Tafsir Al-Mishbah, Volume 2. Ciputat: Lentera Hati.

Suwarno (2001). Muhammadiyah Sebagai Oposisi Studi Tentang Perubahan Perilaku Politik Muhammadiyah Periode 1995, Yogyakarta, UII Press.

Wulansari, P. (2018). Sekulerisasi Politik dan Ulama di Indonesia dalam Perspektif Ahmad Syafii Maarif, Raushan Fikr, 7(2), 235-244.

Yulianto, R. (2020). Islam Moderat Indonesia (Moderasi Muhammadiyah), AlHikmah: Jurnal Studi Agama-Agama, 6(1), 67-97. 